Original Paper http://ajol.info/index.php/ijbcs http://indexmedicus.afro.who.int

\title{
Phytochemical evaluation and GC-MS analysis of Hyptis verticillata cultivated in Calabar Cross River State, Nigeria
}

\author{
Godwin Eneji EGBUNG ${ }^{1 *}$, Chikaodili ANOSIKE ${ }^{1}$, Ashang Bonifice UTU-BAKU, \\ Ironya $\mathrm{OGAR}^{1}$ and Victor Udo NNA ${ }^{2,3}$ \\ ${ }^{1}$ Department of Biochemistry, University of Calabar, P.M.B 1115, Calabar, Nigeria. \\ ${ }^{2}$ Department of Physiology, University of Calabar, P.M.B 1115, Calabar, Nigeria. \\ ${ }^{3}$ Department of Physiology, School of Medical Sciences, Universiti Sains Malaysia, Malaysia. \\ *Corresponding auteur; E-maill: eneji6@gmail.com
}

\begin{abstract}
Hyptis verticillata is a medicinal plant reported to possess strong antioxidant activity growing in the American continent with no evidence of its cultivation in Nigeria. The present study was designed to investigate the phytocompounds present in n-hexane extract of the leaves of $H$. verticillata cultivated in Calabar, Cross River State, Nigeria. The phytochemicals found in relatively high amounts were flavonoids $(19.67 \pm 1.53 \%)$, phenols $(13.20 \pm 0.40 \mathrm{mg} / \mathrm{g})$ and saponins $(7.17 \pm 1.04 \%)$. Others including phytates $(0.42 \pm 0.76$ $\mathrm{mg} / \mathrm{g})$, cyanogenic glycosides $(3.80 \pm 0.20 \%)$ and oxalates $(2.01 \pm 0.09 \%)$ were present in low concentrations. The GC-MS (gas chromatography-mass spectrometry) analysis of the extract revealed fifteen bio-active compounds, mainly hydrocarbons, fatty acid esters and alcohols. The most predominant compounds were, 9,12,15- octadecatrienoic acid, 2,3- bis(acetyloxy) propyl ester (18.17\%), 5-cholestene-3-ol, 24-methyl(17.48\%), 1-iodo-2-methylnonane (10.89\%), glycerol 1,2- dipalmitate (8.19\%), 1- pentadecene (5.18\%), 1hexadecene $(4.80 \%)$ and methyl-14-methylpentadecanoate $(4.76 \%)$. The chemical profile of $H$. verticillata grown in Nigeria is akin to that in the West, hence may serve for similar aromatic and medicinal purposes. (C) 2017 International Formulae Group. All rights reserved.
\end{abstract}

Keywords: Hyptis verticillata, phytocompounds, medicinal plants, GC-MS.

\section{INTRODUCTION}

Hyptis verticillata Jacq. commonly called John Charles in Jamaica, Costa Rica and Belize is a perennial plant that belongs to the plant family Lamiaceae also known as mint family. It is an essential medicinal plant that originates from Central America and has been used traditionally over a long period of time. It is now extending from Florida to other parts of America and the Caribbean countries (Picking et al., 2013). Hyptis verticillata has been used medicinally in Mesoamerica since the times of the Aztec and Mayan cultures (Ocampo and Balick, 2009). It is among the most abundant species of the genus Hyptis and it grows up to the height of one to two meters with slender stems that are well branched; mainly square when they are young. It is dark -green in colour and aromatic in nature, somewhat bitter, being two to $13 \mathrm{~cm}$ long. It has small flowers (aromatic) that are arranged in raceme and have a greenish-white or purple 
corolla that are two millimeters long (Warner, 2007; Picking et al., 2013). The relative lack of botanical description of Hyptis verticillata amongst African authors in the literature is an indication that the plant is alien to the sub Saharan Africa (Oral Communication with a toxicological biochemist, 2016).The plant is used in the complementary treatment of several ailments including asthma, fever, arthritis, gastrointestinal problems, infections, toothache, and herpes amongst other traditional uses. Pharmacological evaluations have shown antimicrobial, anti-inflammatory, anti-cancer, antisecretory, insecticidal and molluscicidal activities (Picking et al., 2013).

Plants produce many chemical compounds that play important roles in influencing biological activities including development of defense against insects, fungi and herbivorous mammals (Tapsell et al., 2006). The mechanisms of action of herbal medicines do not vary greatly from those of the conventional drugs because the chemical compounds present in plants elicit their effect on human body via processes that are similar to those that are already understood for the chemical compounds in conventional drugs (Lai Roy, 2004; Tapsell et al., 2006). These chemical compounds are a product of the plant's secondary metabolism (secondary metabolites) that can only be obtained from plants and are found in an array of plants that are employed as essential components of both human and animal diets including fruits, seeds, herbs and vegetables (Okwu, 2005). The study of these phytochemicals is fundamental to understanding their essential roles in the human system such as protection and treatment of diseases and their likely adverse effects (Arnason et al., 2013). It was imperative therefore, to profile the chemical composition of Hyptis verticillata, a plant originally alien to Calabar, Nigeria, to know whether its essential bioactives were retained. The geographical location, climatic conditions and edaphic factors amongst others, are known to affect the chemical composition of plants and hence their medicinal and aromatic properties (Gairola et al., 2010).

\section{MATERIALS AND METHODS}

Plant material and treatment

Hyptis verticillata was cultivated in a homestead garden in Calabar Municipality, Cross River State, Nigeria, from where the fresh leaves were harvested as shown in Plate 1. The leaves were washed and air dried at room temperature for two weeks. The dried leaves were blended to fine powder and the resulting powder was then extracted in varying reagents and used for analyses.

\section{Phytochemicals evaluation}

Determination of alkaloids was done using the methods of Harborne (1973), flavonoids were estimated by the methods of Bohm and Kocipai-Abyazan (1994). Saponins content was determined by the method of Obadoni and Ochuko (2001), oxalates were determined by the Krishna and Ranjhan (1980) method. The estimation of total phenols was determined using the modified Folin-Ciocalteu method as described by Bello et al. (2011). The phytates content was determined using the method of Griffiths and Thomas (1981) while tannins were determined by the Van-Burden and Robinson (1981) method. The cyanogenic glycosides content was determined by the methods of Sofowara (1993.

\section{GC-MS analysis}

The GC-MS analysis was carried out on a GC-MS (Model: QP2010 plus Shimadzu, Japan) comprising an AOC-20i auto-sampler and gas chromatograph interfaced to a mass spectrometer (GC-MS). The instrument was equipped with a VF5 MS fused silica capillary column of $30 \mathrm{~m}$ length, $0.25 \mathrm{~mm}$ diameter and $0.25 \mu \mathrm{m}$ film thickness. The temperatures employed were; column oven temperature 80 ${ }^{\circ} \mathrm{C}$, injection temperature $250{ }^{\circ} \mathrm{C}$ at a pressure of $108.0 \mathrm{KPa}$ with total flow and column flow of $6.20 \mathrm{ml} / \mathrm{min}$ and $1.58 \mathrm{ml} / \mathrm{min}$ respectively. The linear velocity was $46.3 \mathrm{~cm} / \mathrm{sec}$ and a purge flow of $3.0 \mathrm{ml} / \mathrm{min}$. The GC program ion source and interface temperatures were $230{ }^{\circ} \mathrm{C}$ and $250{ }^{\circ} \mathrm{C}$ respectively, with solvent 
cut time of $2.50 \mathrm{~min}$. The MS program starting time was $3.00 \mathrm{~min}$ which ended at $28.00 \mathrm{~min}$ with event time of $0.50 \mathrm{sec}$, scan speed of $1250 \mu \mathrm{l} / \mathrm{sec}$, scan range $40-800 \mathrm{u}$ and an injection volume of $1 \mu \mathrm{l}$ of the plant extract (split ratio 1.0). The total running time of GCMS was 28 mins. The relative percentage of the analyte was expressed as a percentage with peak area normalization. Interpretation on the mass spectrum was conducted using the database of National Institute of Standards and Technology (NIST) which has over 62,000 patterns. The fragmentation pattern spectra of the unknown components were compared with those of known components stored in the NIST library (NIST Ver. 2.0, 2005). The relative percentage of each phytocomponent was calculated by comparing its average peak area to the total area. The name, molecular weight and structure of the components of the test materials were ascertained in the absence of pure standards (Uraku, 2016, Altemimi et al., 2017).

\section{Data presentation}

The data obtained from this study were presented as mean \pm standard deviation of triplicates determinations.

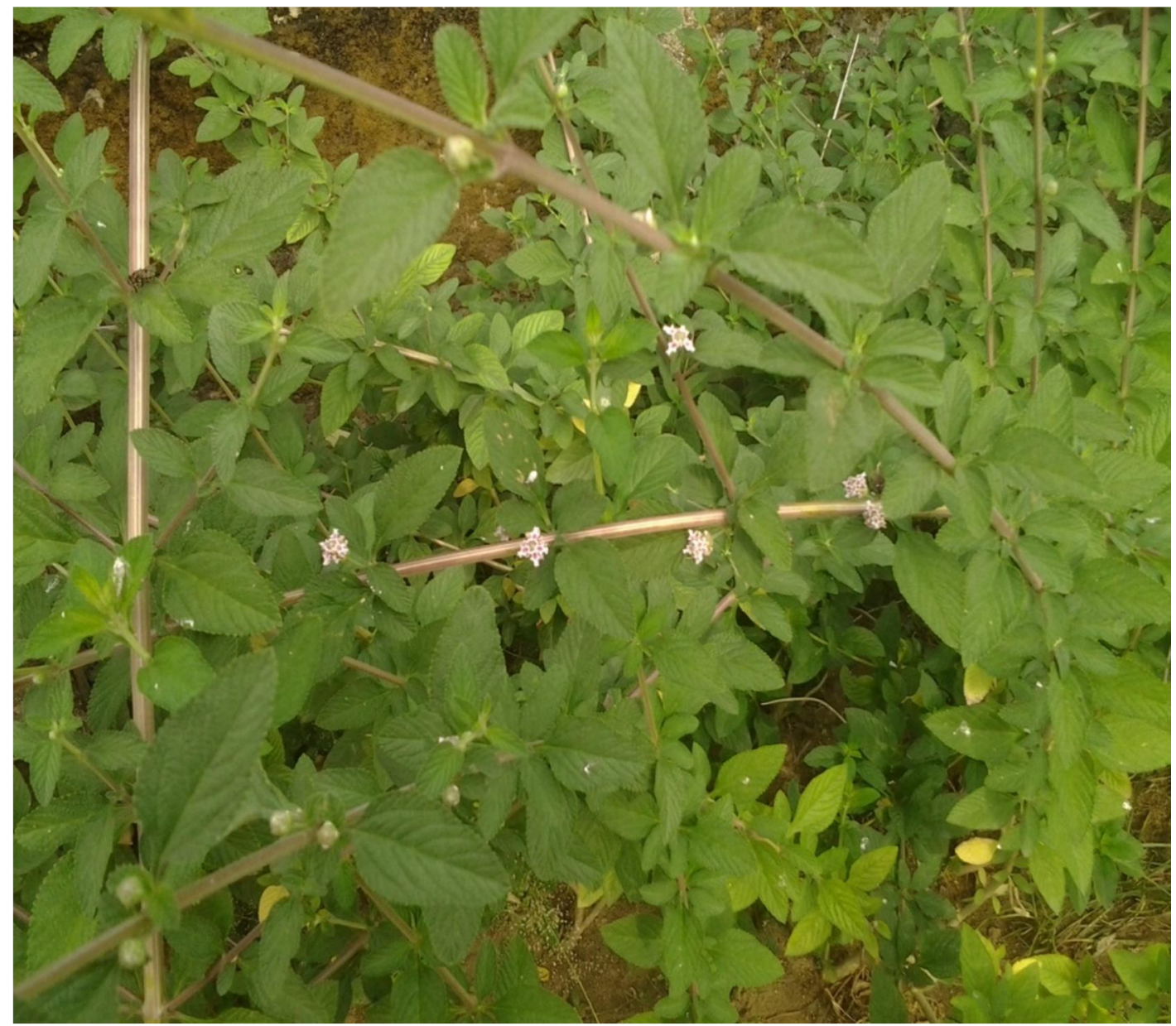

Plate 1: Photograph of Hyptis verticillata Jacq. (Lamiaceae) taken from a homestead garden in Calabar, Cross River State, Nigeria. 


\section{RESULTS}

The result of the quantitative phytochemical evaluation shown in Table 1 indicates the presence of flavonoids and phenols in relatively high concentrations $(19.67 \pm 1.53 \%$ and $13.20 \pm 0.40 \mathrm{mg} / \mathrm{g}$, respectively), saponins and alkaloids in appreciable concentration $(7.17 \pm 1.04 \%$ and $5.67 \pm 0.15 \%$, respectively) whereas the tannins, cyanogenic glycosides, phytates and oxalates were found in relatively low concentration $(4.89 \pm 0.13 \mathrm{mg} / \mathrm{g}, 3.80 \pm 0.20 \%$, $0.42 \pm 0.76 \mathrm{mg} / \mathrm{g}$ and $2.01 \pm 0.09 \%$, respectively) in $H$. verticillata leaves. The
GC-MS chemical profiling of the n-hexane extract of $H$. verticillata leaves shown in figures 2a-2o revealed fifteen bio-active compounds that are mainly hydrocarbons, fatty acid esters and alcohols (Figure 1). The 9,12,15-octadecatrienoic acid,2,3-bis (acetyloxy)propyl ester (18.17\%), 5cholestene-3-ol,24-methyl- (17.48\%), 1-iodo2-methylnonane (10.89\%), glycerol 1,2dipalmitate $(8.19 \%), 1$ - pentadecane $(5.18 \%)$, 1-hexadecene $(4.80 \%)$ and methyl-14methylpentadecanoate $(4.76 \%)$ were the predominant compounds found in the plant extract (Table 2).

Table 1: Phytochemicals and antinutrients composition of $H$. verticillata leaves.

\begin{tabular}{lc}
\hline Parameter & Concentration \\
\hline Alkaloids (\%) & $5.67 \pm 0.15$ \\
Flavonoids (\%) & $19.67 \pm 1.53$ \\
Saponins (\%) & $7.17 \pm 1.04$ \\
Oxalates (\%) & $2.01 \pm 0.09$ \\
Cyanogenic glycosides (\%) & $3.80 \pm 0.20$ \\
Phenols (mg/g) & $13.20 \pm 0.40$ \\
Tannins (mg/g) & $4.89 \pm 0.13$ \\
Phytates (mg/g) & $0.42 \pm 0.76$ \\
\hline
\end{tabular}

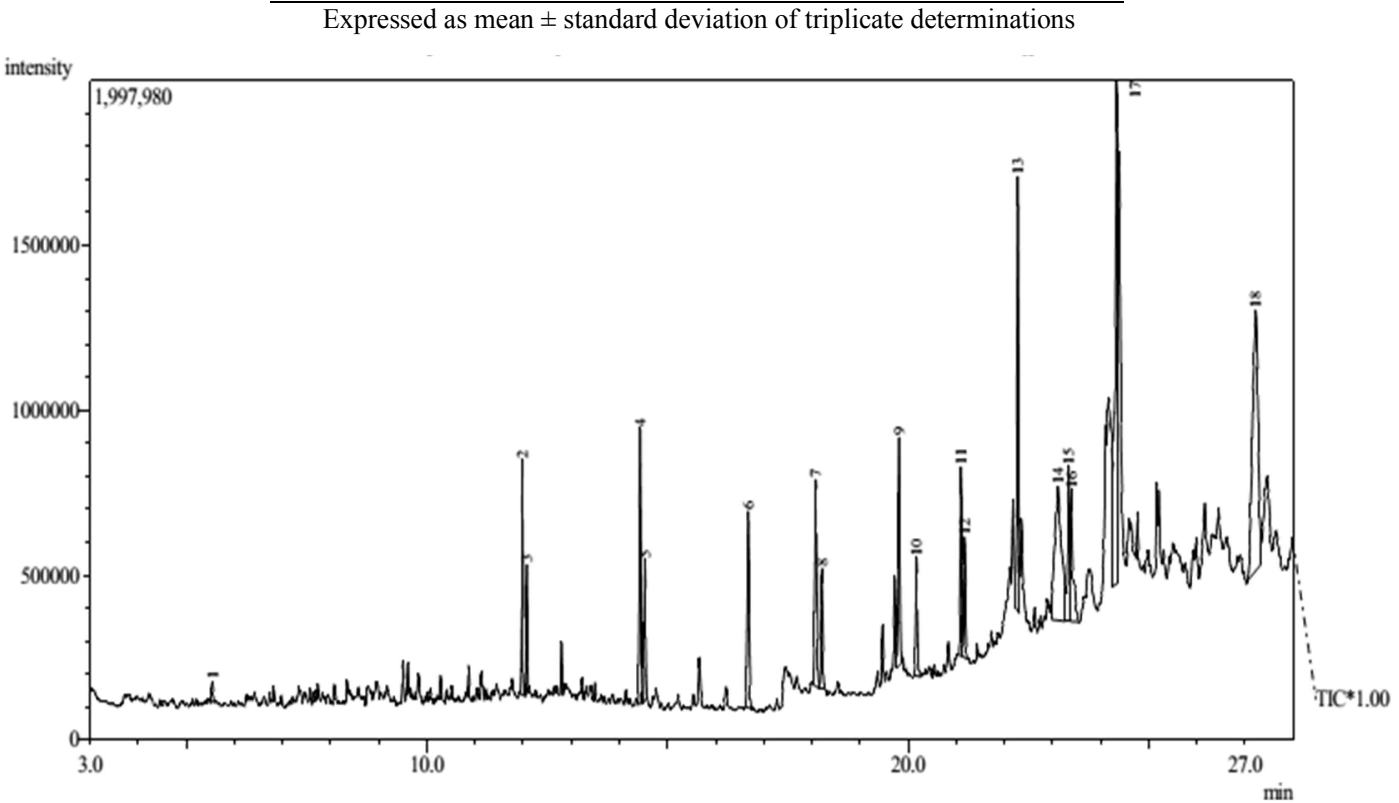

Figure 1: GC-MS chromatogram of the phyto constituents of n-hexane extract from the leaves of $H$. verticillata. 
Table 2: Compounds detected in the n-hexane extract of the leaves of $H$. verticillata.

\begin{tabular}{lllccc}
\hline S/N & $\begin{array}{l}\text { R. Time } \\
\text { (min) }\end{array}$ & Name of compound & $\begin{array}{c}\text { Molecular } \\
\text { formula }\end{array}$ & $\begin{array}{c}\text { Molecular } \\
\text { weight }\end{array}$ & $\begin{array}{c}\text { Total composition } \\
\text { (\%) }\end{array}$ \\
\hline 1. & 5.541 & 1H-pyrrole,2,5-dihydro-1-niroso- & $\mathrm{C}_{4} \mathrm{H}_{6} \mathrm{~N}_{2} \mathrm{O}$ & 98 & 0.42 \\
2. & 11.983 & 2-Tridecene, (Z)- & $\mathrm{C}_{13} \mathrm{H}_{26}$ & 182 & 3.42 \\
3. & 14.429 & 1-Pentadecene & $\mathrm{C}_{15} \mathrm{H}_{30}$ & 210 & 5.18 \\
4. & 16.677 & Methyl 14-methylpentadecanoate & $\mathrm{C}_{17} \mathrm{H}_{34} \mathrm{O}_{2}$ & 270 & 4.76 \\
5. & 18.086 & 1-Hexadecene & $\mathrm{C}_{16} \mathrm{H}_{32}$ & 224 & 4.80 \\
6. & 18.207 & Hexadecane & $\mathrm{C}_{16} \mathrm{H}_{34}$ & 226 & 2.65 \\
7. & 19.812 & 11-Octadecenoic acid, methyl ester & $\mathrm{C}_{19} \mathrm{H}_{36} \mathrm{O}_{2}$ & 296 & 4.60 \\
8. & 20.176 & Octadecanoic acid, methyl ester & $\mathrm{C}_{19} \mathrm{H}_{38} \mathrm{O}_{2}$ & 298 & 2.28 \\
9. & 21.177 & Tridecane & $\mathrm{C}_{13} \mathrm{H}_{28}$ & 184 & 2.20 \\
10. & 22.277 & Glycerol 1,2-dipalmitate & $\mathrm{C}_{35} \mathrm{H}_{68} \mathrm{O}_{5}$ & 568 & 8.19 \\
11. & 23.118 & 1-Iodo-2-methylnonane & $\mathrm{C}_{10} \mathrm{H}_{21} \mathrm{I}$ & 268 & 10.89 \\
12. & 23.336 & 1-Tetracosanol & $\mathrm{C}_{24} \mathrm{H}_{50} \mathrm{O}$ & 354 & 3.58 \\
13. & 23.391 & Eicosane & $\mathrm{C}_{20} \mathrm{H}_{42}$ & 282 & 3.74 \\
14. & 24.336 & 9,12,15-Octadecatrienoic acid,2,3- & $\mathrm{C}_{25} \mathrm{H}_{40} \mathrm{O}_{6}$ & 436 & 18.17 \\
& & bis(acetyloxy)propyl ester, (Z,Z,Z)- & & & \\
15. & 27.223 & 5-Cholestene-3-ol, 24-methyl- & $\mathrm{C}_{24} \mathrm{H}_{48} \mathrm{O}$ & 400 & 17.48 \\
\hline
\end{tabular}

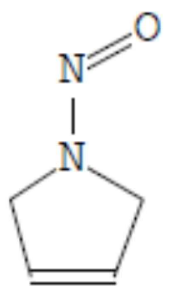

Figure 2a: Structure of 1-Hpyrrole, 2,5-dihydro-1-niroso-

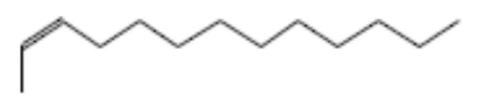

Figure 2b: Structure of 2-Tridecene, (Z)-

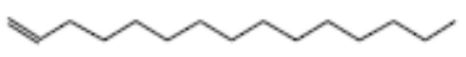

Figure 2c: Structure of 1- Pentadecene.

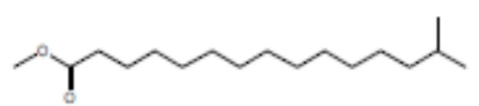

Figure 2d: Structure of methyl 14-methylpentadecanoate 


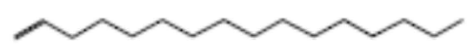

Figure 2e: Structure of 1-Hexadecene.

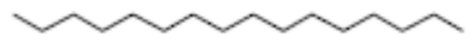

Figure 2f: Structure of Hexadecane.

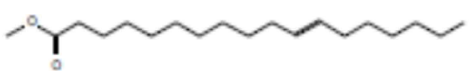

Figure 2g: Structure of 11-Octadecenoic acid, methyl ester.

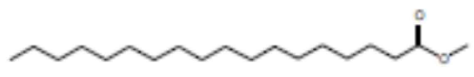

Figure 2h: Structure of Octadecanoic acid, methyl ester.

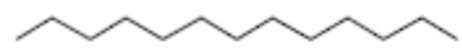

Figure 2i: Structure of Tridecane.

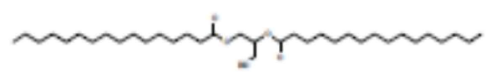

Figure 2j: Structure of Glycerol 1,2-dipalmitate.

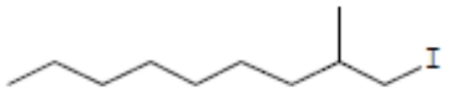

Figure 2k: Structure of 1-Iodo-2-methylnonane.

Figure 2l: Structure of 1-Tetracosanol.

Figure 2m: Structure of Eicosane.

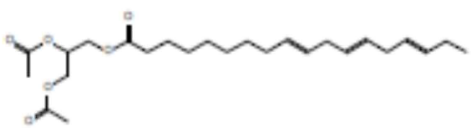

Figure 2n: Structure of 9, 12, 15-Octadecatrienoic acid, 2, 3-bis(acetyloxy)propyl ester, (Z,Z,Z)- 


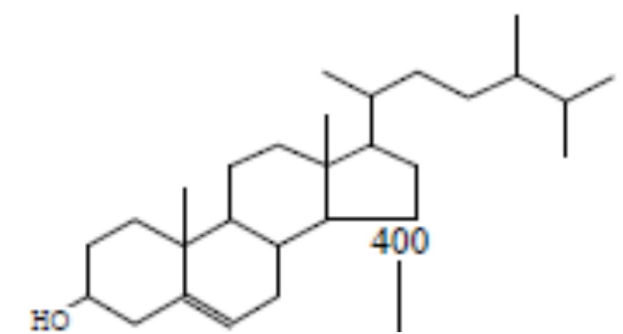

Figure 2o: Structure of 5-Cholestene-3-ol, 24-methyl-

Figure 2: Structures of the compounds detected in the leaves of $H$. verticillata.

\section{DISCUSSION}

Phytochemicals are the chemicals present in plant and these active compounds are isolated for use in modern medicine (Fabricant and Farnsworth, 2001). The results obtained in this study showed that the leaves of the plant are rich in flavonoids, phenols and saponins, whereas phytates, cyanogenic glycosides and oxalates occurred in trace amounts. The flavonoids are polyphenolic compounds and have been recognized to possess pharmacological properties like antioxidative, hepatoprotective, antibacterial, anti-inflammatory, anticancer and also potential antiviral properties (Kumar et al., 2013; Saxena et al., 2013), besides their wellknown antioxidant activity. This foreshows the possible medicinal potentials of the homegrown $H$. verticallata. Phenols are aromatic compounds having one or more hydroxyl group attached to a phenyl ring. They have antioxidant properties and their inhibitory effect on mutagenesis and carcinogenesis is probably their most important activity biologically (Ho, 1992). The result of phenols obtained from this study is higher than those obtained from the stem, root and flowers of Taraxacum officinale, a work reported by Mir et al. (2013) and also higher than the ones got from Solanum indicum (Aberoumand, 2012). Saponins were present in appreciable concentration in $H$. verticillata leaves which was higher than what were observed in the stem, root and flowers of Taraxacum officinale as reported by Mir et al. (2013) and also higher than those for $V$. amygdalina and
O. gratissimum as reported by Udochukwu et al. (2015).

Saponins have been noted to have antimicrobial properties, prevent mould formation and insect attack on plants. They have been included in phyto-protectants which are a group of protective molecules found in plants due to their roles in plant's defense mechanisms (Lacaille-Dubois and Wagner, 2000). They have hypocholesterolemic effect because they reduce certain nutrient uptake e.g. glucose and cholesterol at the gut via intra-luminal physiochemical interaction (Aberoumand, 2012). Alkaloids are a group of chemical compounds that occur naturally, made up of nitrogen ring and are produced by different organisms including bacteria, plants, fungi and animals (Aberoumand, 2012; Saxena et al., 2013). They have been reported to possess a wide range of pharmacological activities which includes: emetic, anticholinergic, antitumor, diuretic, antiviral, antihypertensive and antidepressant amongst others (Aberoumand, 2012). The result obtained for alkaloids is higher than those reported for $V$. amygdalina and $O$. gratissimum by Udochukwu et al. (2015). Tannins are polyphenolic compounds that have astringent, diuretic, anti-inflammatory, antiseptic, antioxidant and haemostatic properties (Dolara et al., 2005; Saxena et al., 2013). They are also used for treatment of gastric and duodenal tumors (Dolara et al., 2005; Saxena et al., 2013). The values of tannins of $H$. verticillata leaves was lower than that reported for $V$. amygdalina but 
higher than that reported for $O$. gratissimum by Udochukwu et al. (2015). The values of saponins, alkaloids and tannins were higher when compared to those reported on fifteen plant species collected at Umudike, Nigeria as reported by Dike (2010). Saponins, alkaloids and tannins are of importance in the different antibiotics that are used in the treatment of common pathogenic strains and it was shown in the work carried out by Kubmarawa (2007) and Mensah (2008). Although phytochemicals have beneficial effects on human health and play a part in the prevention of diseases, they also act as photoprotectant and respond to environmental changes for instance saponins, isoflavones, anthocyanins and flavonoids which play roles in plant's defense mechanisms and also assist them in resisting pathogens (Agte et al., 2000; Lacaille-Dubois and Wagner, 2000). Phytates and oxalates are anti-nutrients and they chelate metals resulting in the formation of insoluble salts thus making them unavailable to the body (Abdoulaye et al., 2011).

Phytates readily chelate calcium, iron and zinc while oxalates chelate magnesium and calcium but most especially calcium, forming calcium-oxalate crystals which can lead to kidney stone development (Abdoulaye et al., 2011; Norris, 2013). Beside the negative effect of phytate which seemed to be its only pharmacological activity it has been evidenced recently to have antioxidant, anticancer, hypocholesterolemic and hypolipidemic properties. It can also inhibit polyphenol oxidase which causes oxidative browning in fruits and vegetables and reduces the oxidative reactions that are catalyzed by iron (Aberoumand, 2012). Hydrogen cyanides are released when fresh plant materials that contain cyanogenic glycosides are macerated permitting the reaction between enzymes and cyanogenic glycosides (Magnuson, 1997). Cyanide is one of the most potent and rapidly acting poisons known in plant food and it is shown to be very low in $H$. verticillata leaves alongside oxalates and phytates (Table 1). It can cause the death of cells by interfering with the oxidative processes. The human body can detoxify cyanide quickly, therefore can withstand a concentration of 50-60 ppm per hour without fatal consequences but conversely at the concentration of 200-500 ppm for 30 minutes (Magnuson, 1997).

The gas chromatography-mass spectrometry (GC-MS) analysis indicated that $H$. verticillata leaves contains fifteen bioactive compounds that are mainly hydrocarbons, fatty acid esters and alcohols namely: 9,12,15-octadecatrienoic acid,2,3bis(acetyloxy)propyl ester, 5-cholestene-3ol,24-methyl-; 1-iodo-2-methylnonane; glycerol 1,2- dipalmitate; 1- pentadecene; 1hexadecene and methyl-14methylpentadecanoate which were the predominant compounds found in the leaves of the plant (Table 2). The 9,12,15octadecatrienoic acid,2,3- bis(acetyloxy) propyl ester, is an unsaturated fatty acid ester which has been shown to possess antiinflammatory, hypocholesterolemic, cancer preventive, hepatoprotective, nematicide, insectifuge, antihistaminic, antieczemic, antiacne, 5-alpha reductase inhibitor, antiandrogenic, antiarthritic and anticoronary activities (Dhayabaran and Thangarathinam, 2016), while 5-cholestene-3-ol,24-methylwhich is a steroid possesses antimicrobial, anti-inflammatory, anticancer, diuretic, antiarthritic and antiasthma activities as reported by Dhayabaran and Thangarathinam (2016). The result obtained for 9,12,15octadecatrienoic acid,2,3- bis(acetyloxy) propyl ester (18.17\%) and 5-cholestene-3ol,24-methyl- (17.48\%) from the leaves of $H$. verticillata is higher than that of the ethanolic extract of Senna uniflora whole plant as reported by Dhayabaran and Thangarathinam (2016). 1-tetracosanol which is an alcoholic compound have been known for its antibacterial activity as reported by Kuppuswamy et al. (2013) and the value obtained in the present study (Table 2) is lower than that reported on the chloroform leaf extract of Croton bonplandianum by Kuppuswamy et al. (2013). The 1-iodo-2methylnonane is an iodo compound and have 
antimicrobial activity according to the work of Jasmine et al. (2013), the result obtained for 1-iodo-2-methylnonane $(10.89 \%)$ is higher than that reported on decholestrate (a polyherbal formulation) by Jasmine et al. (2013). According to Akpuaka et al. (2013), hexadecane is a hydrocarbon that possesses antioxidant, antifungal and antibacterial activities, eicosane which is a fatty acid have antibacterial, antitumor and cytotoxic activities while methyl 14methylpentadecanoate have antifungal and antimicrobial activities and octadecanoic acid, methyl ester possesses antifungal, antimicrobial and antibacterial activities.

The results obtained for hexadecane (Table 2) is lower when compared to those reported by Yogeswari et al. (2012) and Ardalan et al. (2016). The values of eicosane (3.74\%) obtained from $H$. verticillata is lower than that reported by Jasmine et al. (2013) and Kumar et al. (2011) while that of octadecanoic acid, methyl ester is lower as compared to the work reported on the methanolic extract of the seed and root of Rorippa indica (Ananthi and Ranjitha, 2013). The 1-pentadecene is a hydrocarbon that has antibacterial activity based on the study of Kumar et al. (2011) and the result obtained from this study is higher than those reported on Actinotrichia fragilis by Ardalan et al. (2016) and Kumar et al. (2011), respectively, while $1 \mathrm{H}$-pyrrole,2,5dihydro-1-niroso- which is a nitro compound possess antibacterial, antiviral, anticonvulsant and analgesic properties as reported by Sosa et al. (2016). 1-hexadecene is a long chain fatty acid that has antibacterial activity as reported by Kuppuswamy et al. (2013), the values of 1hexadecene $(4.80 \%)$ obtained from this study is higher than those reported on the chloroform fraction but lower than the dichloromethane fraction of Monochaetia kansensis as reported by Yogeswari et al. (2012) and also lower than that reported by Kumar et al. (2011). The result obtained from $H$. verticillata indicated that percentage concentration of 2-tridecene (3.42\%) is higher than that of Colpomenia sinuosa a work reported by Ardalan et al. (2016) while that of tridecane is higher than the values obtained for Actinotrichia fragilis but lower than that of $C$ sinuosa as reported by Ardalan et al. (2016).

Generally, some plant foods when not consumed as snacks or food are administered for the purpose of treating certain diseases and $H$. verticillata has been exploited traditionally for its anti-inflammatory, antimicrobial, antioxidant, hepatoprotective potentials amongst other therapeutic benefits in the American continent with no evidence of its cultivation/use in Nigeria (Umoh, 1998; Picking et al., 2013). The medicinal value of the leaves of $H$. verticillata is probably because of the presence of flavonoids, saponins and phenols which were present in elevated levels.

\section{Conclusion}

The present study investigated the phyto constituents of $H$. verticillata leaves cultivated in Calabar, Cross River State, Nigeria. $H$. verticillata leaves were found to possess a number of phytochemicals, some of which were present in appreciable concentrations (flavonoids, phenols, saponins and alkaloids) while the antinutrients were in very low concentrations. Fifteen bioactive compounds were identified in the plant using GC-MS analysis where 9,12,15octadecatrienoic acid,2,3- bis(acetyloxy) propyl ester, ; 5-cholestene-3-ol,24-methyl-; 1-iodo-2-methylnonane; glycerol 1,2dipalmitate; 1- pentadecene; 1-hexadecene and methyl-14-methylpentadecanoate were the predominant ones. These compounds are known to possess mainly antifungal, antibacterial, antioxidant, anti-inflammatory, hypocholesterolemic, anticancer, anticoronary, 5-alpha reductase inhibitor and antimicrobial activities. These data obtained suggests that $H$. verticillata leaves may be a good source of medicinal and aromatic compounds relevant in the nutraceutical and cosmetic industry. Also it is a potential 
source of a complement of antioxidant compounds.

\section{COMPETING INTERESTS} interests.

The authors have no competing

\section{AUTHORS' CONTRIBUTIONS}

GEE designed and supervised the work, CA carried out the work, ABU-B, IO and VUN provided some literature information and also read and approve the final manuscript.

\section{ACKNOWLEDGEMENTS}

The authors are grateful to Dr Justin Item Atangwho for constructive advice during the design of this work. We are grateful to $\mathrm{Mr}$ Ibrahim Wahala of National Research Institute for Chemical Technology, Zaria, Nigeria, for his technical assistance in GC-MS analysis and $\mathrm{Mr}$ Andrew Ushie for assisting during plant cultivation and harvest of the Hyptis verticillata leaves.

\section{REFERENCES}

Abdoulaye C, Brou K, Jie C. 2011. Phytic acid in cereal grains: structure, healthy or harmful ways to reduce phytic acid in cereal grains and their effects on nutritional quality. Am. J. Plant Nutr. Fertn. Tech., 1(1): 1-22. https://doi.org/10.3923/ajpnft.2011.1.22

Aberoumand A. 2012. Screening of phytochemical compounds and toxic proteinaceous protease inhibitors in some lesser- known food based plants and their effects and potential applications in food. Intl. J. Fd. Sci. Nutr. $\quad$ Engr., 2(3): 16-20. https://doi.org/10.5923/j.food.20120203. 01

Agte VV, Tarwadi KV, Megale S, Chiplonkar SA. 2000. Potential of indigenous green vegetables as natural sources of fortification of eight micronutrients. $J$. Fd. Compn Analys.,13: 885-891. https://doi.org/10.1006/jfca.2000.0942
Akpuaka A, Ekwenchi MM, Dashak DA, Dildar A. 2013. Biological activities of characterized isolates of n- hexane extract of Azadirachta indica Jusss (Neem) leaves. New York Sci. J., 6(6): 119-124.

Altemimi A, Lakhssassi N, Baharlouei A, Watson DG, Lightfoot DA. 2017. Phytochemicals: Extraction, Isolation, and Identification of Bioactive Compounds from Plant Extracts. Plants, 6(4): 42; doi:10.3390/plants6040042

Ananthi BD, Ranjitha K. 2013. GC-MS determination of bioactive components of Rorippa indica L. Intl. J. Chem. Tech. Res., 5(4): 2027-2033.

Ardalan P, Azadeh H, Nazim M. 2016. Antibacterial and insecticidal activity of volatile compounds of three algae species of Oman Sea. Intl. J. Sec. Metabolite, 3(2): 66-73.

Arnason JT, Maka R, Romeo JT. 2013. Phytochem. of Med. Plants. SpringerVerlag New York Inc. New York, United States; 364 p.

Bello A, Aliero AA, Saidu Y, Muhammad S. 2011. Phytochemical screening, polyphenolic content and alphaglucosidase inhibitory potential of Leptadenia hastate (Pers.) Decne. Nig. J. Basic and Appl. Sci., 19(2): 181-186.

Bohm BA, Kocipai-Abyazan R. 1994. Flavonoid and condensed tannins from the leaves of Vaccinum raticulation and Vaccinum calcyimium. Pacific Sci., 48: 458-463.

Dhayabaran VV, Thangarathinam J. 2016. Gas chromatography- mass spectroscopy analysis of Senna uniflora (Mill.) Irwin and barneby whole plant. J. Nat. Prod. Res., 2(1): 37-39.

Dike MC. 2010. Proximate, phytochemical and nutrient compositions of some fruits, seeds and leaves of some plant species at Umudike, Nigeria. Asian Res. Publishing Network (ARPN) J. Agric. Biol. Sci., 5(1): 7-16.

Dolara P, Luceri C, De Filippo C, Femia AP, Giovannelli L, Carderni C, Silvi, S, 
Orpianesi C, Cresci A. 2005. Red wine polyphenols influence carcinogenesis, intestinal microflora, oxidative damage and gene expression profiles of colonic mucosa in F344 rats. Mutn. Res., 591: 237-246. https://doi.org/10.1016/ j.mrfmmm.2005.04.022

Fabricant DS, Farnsworth NK. 2001. The value of plants used in traditional medicine for drug discovery. Environ. Health Persp., 109(1): 69-75. https://doi.org/10.2307/3434847

Gairola S, Shariff NM, Bhatt A, Kala CP. 2010. Influence of climate change on production of secondary chemicals in high altitude medicinal plants: Issues needs immediate attention. J. Med. Plants Res., 4(18): 1825-1829.

Griffiths DW, Thomas T A. 1981. Phytate and total phosphorus content of various field bean (Viciafabia L.). J. Sci. Fd. Agric., 32: 187-192. https://doi.org/ 10.1002/jsfa.2740320215

Harborne JB. 1973. Method of plant analysis. In Phytochemical Methods. Chapman and Hall: London.

Ho CT. 1992. Phenolic compounds in foodan overview. In Phenolic Compound and their Effects on Health I. American chemical society symposium series 506 : Washington D.C; 2-7.

Jasmine MJ, Latha K, Vanaja R. 2013. Determination of bioactive components of decholestrate, a polyherbal formulation by GC-MS analysis. New York Sci. J., 6(5): 1-5.

Krishna G, Ranjhan SK, 1980. Laboratory Manual for Nutrition Research. Vikas Publication House; PVT Ltd.: New Delhi; 134.

Kubmarawa D, Ajoku GA, Enworem NM, Okorie DA. 2007. Roles of agricultural biotechnology in ensuring adequate food security in developing societies. Afri. $J$. Biotech., 6: 1690-1696.

Kumar S, Pandey AK. 2013. Chemistry and biological activities of flavonoids: An overview. The Sci. World J., 11: 1-16. https://doi.org/10.1155/2013/962185
Kumar V, Bhatnagar AK, Srivastava JN. 2011. Antibacterial activity of crude extracts of Spirulina plantensis and its structural elucidation of bioactive compound. J. Med. Plants Res., 5(32): 7043-7048.

Kuppuswamy KM, Jonnalagadda B, Arockiasamy S. 2013. GS-MS analysis of chloroform extract of Croton bonplandianum. Intl. J. Pharm. Biol. Sci., 4(4): 613-617.

Lacaille-Dubois MA, Wagner $\mathrm{H}$. 2000. Bioactive saponins from plants: an update. In Studies in Natural Products Chemistry, Atta-Ur-Rahman (Ed.). Elsevier Science; 21: 633-687.

Lai PK, Roy J. 2004. Antimicrobial and chemo preventive properties of herbs and spices. Cur. Med. Chem., 11(11):1451$1460 . \quad$ https://doi.org/10.2174/ 0929867043365107

Magnuson B. 1997. Cyanogenic Glycosides. EXTOXNET FAQS TEAM. Accessed at http://extoxnet.orst.edu/faqs/natural/cya. htm on 13/07/2016.

Mensah J, Okoli RL, Ohaju- Ohodo JO, Eifediyi K. 2008. Aqueous extract of Telfairia occidentalis leaves reduces blood sugar and increases haematological and reproductive indices male rats. Afri. J. Biotech., 7:2304-2309.

Mir MA, Sawhney SS, Jassal MMS. 2013. Quanlitative and quantitative analysis of phytochemicals of Taraxacum officinale. Wudpecker J. Pharm. Pharmacology, 2(1): 001-005.

Norris J. 2013. Oxalate. Nutrient Recommendation and Research. Accessed at veganhealth.org/ article/oxalate on 13/07/2016.

Obadoni BO, Ochuko PO. 2001. Phytochemical studies and comparative efficacy of the crude extract of some homeostatic plants in Edo and Delta States of Nigeria. Global J. Pure Appl. Sci., 8: 203-208.

Ocampo R, Balick M. 2009. Plants of Semillas Sagradas: an Ethnomedicinal 
Garden in Costa Rica. San Jose, Finca Luna Nueva Extractos de Costa Rica.

Okwu DE. 2005. Phytochemicals, vitamins and minerals contents of two Nigerian medicinal plants. Intl. J. Mol. Med. Adv.Sci., 1: 375-381.

Olufunke MD. 2012. Developments in Phytochemistry. Drug Discovery Research in Pharmacognosy, Prof. Omboon Vallisuta (Ed.). available from: http://www.intechopen.com/books.drugdiscovery-reserach-inpharmacognosy/developments-inphytochemistry. Retrieved 14/10/2016

Picking D, Delgoda R, Boulogne L, Mitchell S. 2013. Hyptis verticillata Jacq: A review of its traditional uses, phytochemistry, pharmacology and toxicology. J. Ethnopharm., 147(1): 1641. https://doi.org/10.1016/j.jep. 2013.01.039

Saxena M, Saxena J, Nema R, Singh D , Gupta A. 2013. Phytochemistry of medicinal plants. J. Pharm. Phytochem., 1(6): 168-182.

Sofowara A. 1993. African Medicinal Plants. University of Ile Ife Press: Ile Ife, Nigeria.

Soladoye MO, Chukwuma EC. 2012. Quantitative phytochemical profile of the leaves of Cissus Populnea Guill. \& Perr. (vitaceae)- an important medicinal plant in central Nigerian. Arch. Appl.Sci. Res., 4(I): 200-206.

Sosa AA, Bagi SH, Hameed IH. 2016. Analysis of bioactive chemical compounds of Euphorbia lathymus using gas chromatography- mass spectrometry and Fourier- Transform Infrared spectroscopy. J. Pharm. Phytotherapy, 8(5):109-126. https://doi.org/10.5897/ JPP2015.0371

Swain DS, Tony RA. 1968. Plants in the Development of Modern Medicine. Harvard university press: Cambridge.

Tapsell LC, Hemphill I, Cobiac L. 2006. Health benefits of herbs and spices: the past, the present the future. Med. J. Australia, 185(4): 4-24.

Udochukwu U, Omeje FI, Uloma IS, Oseiwe FD. 2015. Phytochemical analysis of Vernonia amygdalina and Ocimum gratissimum extracts and their antibacterial activity on some drug resistant bacteria. Amer. J. Res. Comm., 3(5): 225-235.

Umoh IB. 1998. Commonly Used Fruits in Nigeria. In nutritional Quality of Plant Foods. Post-Harvest Research Unit University of Benin: Benin City; 221244.

Uraku AJ. 2016. GC/MS study of phytocompounds from the leaves of sweet basil. EC Pharm. Sci., 2(2): 265277.

Van-Burden TP, Robinson T. 1981. The Biochemistry of Alkaloids ( $2^{\text {nd }}$ edn). Springer-Verlag New York Inc.: New York.

Warner M. 2007. Herbal Plants of Jamaica. MacMillan Caribbean: Portsmouth, NH, U.S.A.

Yogeswari S, Ramalakshmi S, Neelavathy R, Muthumary J. 2012. Identification and comparative studies of different volatile fractions from Monochaetia kansensis by GC-MS. Global J. Pharm., 6(2): 65-71. 